\title{
School Accountability and Residential Location Patterns: Evaluating the Unintended Consequences of No Child Left Behind
}

\author{
by
}

\author{
Keren Mertens Horn \\ University of Massachusetts Boston
}

\begin{abstract}
CES 17-28
March, 2017

The research program of the Center for Economic Studies (CES) produces a wide range of economic analyses to improve the statistical programs of the U.S. Census Bureau. Many of these analyses take the form of CES research papers. The papers have not undergone the review accorded Census Bureau publications and no endorsement should be inferred. Any opinions and conclusions expressed herein are those of the author(s) and do not necessarily represent the views of the U.S. Census Bureau. All results have been reviewed to ensure that no confidential information is disclosed. Republication in whole or part must be cleared with the authors.

To obtain information about the series, see www.census.gov/ces or contact J. David Brown, Editor, Discussion Papers, U.S. Census Bureau, Center for Economic Studies 5K034A, 4600 Silver Hill Road, Washington, DC 20233, CES.Working.Papers@census.gov. To subscribe to the series, please click here.
\end{abstract}




\begin{abstract}
The 2002 to 2015 No Child Left Behind (NCLB) Act is often considered the most significant federal intervention into education in the United States since 1965 with the passage of the Elementary and Secondary Education Act. There is growing evidence that holding schools accountable is leading to some improved educational outcomes for students. There is in contrast very little work examining whether these sweeping reforms have unintended consequences for the communities which these schools are serving. As school attendance, particularly at the elementary school level, is closely tied to one's residence, placing sanctions on a school could have negative repercussions for neighborhoods if it provides new information on school failure. In contrast, if these sanctions also bring new resources, including financial resources or school choice, they could spark additional demand within a neighborhood. Through the use of restricted access census data, which includes local housing values, rents and individual residential choices in combination with the use of a boundary discontinuity identification strategy, this paper seeks to examine how failure to meet Adequate Yearly Progress (AYP), the key enforcement mechanism of NCLB, is shaping local housing markets and residential choices in five diverse urban school districts: New York, Los Angeles, Philadelphia, Detroit and Tucson.
\end{abstract}

\footnotetext{
* Any opinions and conclusions expressed herein are those of the author and do not necessarily represent the views of the U.S. Census Bureau. All results have been reviewed to ensure that no confidential information is disclosed.The research in this paper was conducted while the author was a Special Sworn Status researcher of the U.S. Census Bureau at the New York Census Research Data Center.
} 


\section{Introduction}

The 2002 to 2015 No Child Left Behind (NCLB) Act is often considered the most significant federal intervention into education in the United States since 1965 with the passage of the Elementary and Secondary Education Act (Dee and Jacob, 2011). There is growing evidence that holding schools accountable is leading to some improved educational outcomes for students (Carnoy and Loeb, 2002; Hanushek and Raymond, 2005; Jacob, 2005; Figlio and Rouse, 2006; West and Peterson, 2006; Reback, 2008; Rockoff and Turner, 2010; Dee and Jacob, 2011; Chakrabarti, 2013; Reback, Rockoff and Schwartz, 2014). There is in contrast very little work examining whether these sweeping reforms have unintended consequences for the communities which these schools are serving. ${ }^{1}$ As school attendance, particularly at the elementary school level, is closely tied to one's residence, placing sanctions on a school could have negative repercussions for neighborhoods if it provides new information on school failure. In contrast, if these sanctions also bring new resources, including financial resources or school choice, they could spark additional demand within a neighborhood.

Through the use of restricted access census data, which includes local housing values, rents and individual residential choices in combination with the use of a boundary discontinuity identification strategy, this paper seeks to examine how failure to meet Adequate Yearly Progress (AYP), the key enforcement mechanism of NCLB, is shaping local housing markets and residential choices in five diverse urban school districts: New York, Los Angeles, Philadelphia, Detroit and Tucson.

There is a sizeable literature documenting the importance of schools in housing markets through their impact on residential sorting. Black and Machin (2010) Nguyen-Hoang and Yinger

\footnotetext{
${ }^{11}$ Exceptions include Billings, Brunner and Ross, 2014 and Bogin and Nguyen-Hoang, discussed below.
} 
(2011) review this literature that spans many countries and a wide variety of identification strategies and report consistent findings that housing values are higher in places where measured school quality is higher. They conclude that parents are willing to pay substantial amounts of money to ensure that their child is educated in a better school; specifically, a one standard deviation increase in test scores raises house prices by approximately 3 percent.

There is a small, but growing body of literature documenting how households are responding to school reforms and examining the implications of these responses for housing markets. Baum-Snow and Lutz (2011) and Boustan (2012) examine the unintended consequences of school desegregation, and that although desegregation did lead to increased exposure of minority students to white students (Reber, 2005) these policies also led to white flight from central cities as well as declines in urban housing values of approximately 6 percent. Figlio and Lucas (2004) show that receipt of an 'A' grade in Florida is capitalized into housing values and they are able to document that households with high achieving children respond to grades, as they are more likely to select a neighborhood with an "A" school when they change metropolitan areas. Cellini, Ferreira and Rothstein (2010) examine capital spending on schools, estimating that the willingness to pay of the marginal homebuyer is $\$ 1.50$ for each $\$ 1$ of capital spending. More recently, a few authors have examined the impacts of both inter and intra district school choice on housing values, finding that neighborhoods receiving students experience declines in property values whereas neighborhoods sending students experience increases in housing values (Reback, 2005; Brunner, Cho and Reback, 2012; Machin and Salvanes, 2010; Schwartz, Voicu and Horn, 2014; McMillen, 2015).

In contrast, there has been almost no work studying how No Child Left Behind (NCLB) may be shaping household residential choices. NCLB was motivated by the belief that when 
schools are held accountable for student performance, through the dissemination of information to parents and the enforcement of severe consequences for failing to meet Adequate Yearly Progress (AYP) for two consecutive years, this pressure will encourage administrators and teachers to do the work necessary to improve their schools. After a school has been identified as failing to meet AYP for two years, they enter 'program improvement' which could stigmatize a school and the surrounding neighborhood, leading to declines in housing values. Alternatively if entering program improvement is not providing any new information on school quality, but rather is serving as a signal that investments will be made in the neighborhood school, this could spur interest in the neighborhood. The impact of having a failing school could also vary based on the neighborhood. In high value neighborhoods it may be more likely that entering program improvement could signal a turnaround for the neighborhood school.

There are two recent papers that have examined the impacts of failure to meet AYP on local housing markets in Charlotte-Mecklenberg. Bogin and Nguyen-Hoang (2014) employ a hedonic estimation strategy and find that on average failure to meet Adequate Yearly Progress (AYP) significantly decreases housing values. Billings, Bruner and Ross (2014) separately examine high value and low value neighborhoods, in addition to employing a boundary discontinuity approach, and find that though in low value neighborhoods failure to meet AYP is associated with declines in housing values, in moderate and high value neighborhoods, failure to meet AYP is associated with increases in housing values. They posit that this impact is driven by the priority status for charter school lotteries given to households in neighborhoods with schools in program improvement. Charlotte-Mecklenberg is known as a school district with an extremely high level of school choice. In contrast, the five school districts in this sample have much smaller levels of school choice. This research will expand existing knowledge by 
examining how households respond to information that schools are failing to meet AYP in five diverse urban school districts, utilizing confidential census data in combination with a boundary discontinuity approach to clearly identify this relationship.

\section{Background: No Child Left Behind}

No Child Left Behind was signed into law in 2002 and officially ended in 2015. NCLB required each state to adopt an accountability system that is based on student proficiency in math and reading, including performance within student subgroups (such as low income students, minority students and those with limited English proficiency). Schools were then required to achieve higher levels of proficiency each year (the specific target is determined by the State Department of Education), and by 2014 each school was required to reach 100 percent proficiency (though many states received waivers from this requirement).

Schools that fail to meet their given proficiency target, or Adequate Yearly Progress (AYP), face a series of increasingly severe sanctions. If a school fails to meet AYP they are required to notify all parents and offer them school choice options as well as supplemental services. If a school fails to meet AYP for 5 consecutive years they must completely restructure or will face school closure.

\section{Data}

To conduct this analysis I rely on the confidential versions of the 2000 Decennial Census and the American Community Survey between 2005 through 2009. The confidential versions of these datasets provide information on the census block in which each household lives. This allows me to follow census blocks over time and observe how demand for housing in these 
neighborhoods changes over time as well as the composition of households within these neighborhoods.

I focus on large urban school districts, as urban school districts make up 5 percent of overall school districts, but educate 29 percent of public school children, 38 percent of the nation's poor children and 44 percent of the nation's black and Hispanic children. ${ }^{2}$ I selected the largest urban school districts for which I was able to attain both school attendance zone boundaries and information on school proficiency rates along with AYP status: New York, Los Angeles, Philadelphia, Detroit and Tucson.

For these five cities, I merge the census blocks in these urban school districts to school attendance zone boundaries which I obtained through the School Attendance Boundary Information System (SABINS). This dataset was constructed by Sal Saporito at the College of William and Mary and is the first comprehensive effort to assemble digital data of elementary, middle and high school attendance zone boundaries. Information on the AYP status of a school is available through each individual state's Department of Education. I track whether a school has failed to make AYP in a given year and then whether they fail again in the following year or are able to exit probation. Schools that fail to meet AYP for two consecutive years are then tagged as entering 'program improvement.' I then supplement these data with test score data for each school, provided through the state department of education.

Table 1 provides some descriptive information on each of these urban school districts. We can see that these are five very different cities in terms of basic demographic characteristics. Los Angeles and Tucson have an extremely large share of Hispanic households, while Detroit is almost entirely composed of black households. Philadelphia also has a very large black

\footnotetext{
${ }^{2}$ http://nces.ed.gov/programs/coe/indicator_tla.asp\#info
} 
population, and New York has more of a mix of black and Hispanic households. The poverty rates in these cities are all high, ranging from 19 percent in New York and Los Angeles to 34 percent in Detroit. Taking a look at the share of households that rely on the public school system, in all of these cities the vast majority of school aged children attend public schools, ranging from a low of 80 percent in Philadelphia and New York to a high of 93 percent in Detroit and Tucson.

Next Table 2 presents a picture of the public schools in each of these urban school districts. We see that there is wide variation in the size of each of these school districts reflecting the different sizes of each of these cities. New York City has almost 1,500 schools, whereas Tucson has only 125 schools. These schools also serve very different populations. Only 2.5 percent of students in the Detroit public school system are white, in comparison to almost 30 percent in Tucson. In Detroit the overwhelming majority of students are black, 87 percent, with Tucson again at the other extreme, with only 7.5 percent black students. In contrast, in Los Angeles 73 percent of students are Hispanic, with Detroit at the other extreme, with a Hispanic population of just 8 percent. In almost all of these cities the overwhelming majority of students are eligible for free and reduced price lunch, at about 75 percent. In Tucson a much lower share are eligible for free and reduced price lunch, but this share is still quite high at 55 percent.

Table 3 describes the share of public schools that failed to meet AYP in each city during the sample period. New York City consistently has the smallest share of schools failing to meet AYP, whereas Philadelphia has the largest share of schools failing to meet AYP. As these school districts are quite different, it is critical that my analyses focus on changes within school districts, specifically across attendance zone boundaries within a single school district. 


\section{Empirical Approach/Methodology}

This analysis identifies the impact of failing to meet AYP on the local housing market, observing changes in self-reported housing values and rents, and then further examining changes in the composition of households in a school zone after the school enters program improvement. In addition to utilizing confidential micro-data linked to elementary school attendance zone boundaries, I employ a boundary discontinuity approach to isolate the impacts of entering program improvement on neighborhood change. One primary concern with identifying how school reforms affect housing demand is with omitted variable bias, as neighborhoods with failing schools are likely different from neighborhoods without failing schools in potentially unobservable ways. The boundary discontinuity approach can help distinguish the influence of the school reform from these underlying differences as it takes advantage of the fact that neighborhood characteristics change smoothly over distances, such as the distance to cultural amenities or public transportation, but school characteristics change discontinuously at the attendance zone boundary. I compare census blocks that are very close to one another (and share many of the same neighborhood characteristics), but are located in different elementary school attendance zones, allowing me to identify the consequences of the associated NCLB school reform.

To implement this methodology, I use a panel of census blocks. ${ }^{3}$ I aggregate the census blocks that are in the same school district and include observations close to the attendance zone boundary (within 1,000 feet) on either side. I define these clusters as 'boundary groups,' as these boundary groups are composed of adjoining census blocks. This method removes the

\footnotetext{
${ }^{3}$ Data from the Decennial Census and ACS is available at the census block level. Since I rely on data at the census block level, I do not create a perfect boundary discontinuity, but as found by Bayer, Ferreira and McMillan (2007) this level of geography is extremely fine and can be used to define a very narrow band around the attendance zone boundary.
} 
unobserved variations in neighborhoods. Since I focus on elementary schools within the same school district, I eliminate differences in local taxes. I then compare two census blocks that are embedded in the same neighborhood that differs only by the elementary school.

To examine whether this approach overcomes some of the concerns regarding omitted variables I run a balancing test, examining whether the side of the boundary with a school that ever failed to meet AYP looks similar to the side that never failed based on observable characteristics in 2005, the baseline period. Results are presented in Table 4. Column 1 shows results of the regression without boundary group fixed effects, showing that neighborhoods with a school that at one point during the study period was in program improvement have very different populations than those neighborhoods whose school was never in program improvement. Column 2 shows that once boundary group effects are included, meaning that comparisons are made among housing units that are on opposite sides of an attendance zone boundary, there are now fewer observable differences in household and housing characteristics. There is still some difference in presence of college educated and Hispanic households, but the magnitude of these differences declines substantially. In terms of housing units, there are almost no differences in the housing stock once boundary group fixed effects are incorporated into the comparison. Results of the balancing test show that at least on observable characteristics, units in the same boundary group but on different sides of an elementary school boundary look similar in terms of baseline characteristics.

\section{Empirical Estimation}

To formalize this relationship, I estimate the following empirical model. 
$\mathrm{Y}_{\mathrm{izgdt}}=\alpha_{1}$ EverPI $_{\mathrm{zgd}}+\alpha_{2} \mathrm{PI}_{\mathrm{zgdt}-1}+\alpha_{3}$ PostPI $_{\mathrm{zgdt}-1}+\beta_{1} \mathrm{PI}^{*}$ Terc23 $3_{\text {zgdt-1 }}+\beta_{2}$ PostPI Terc23 $_{\text {zgdt-1 }}+$

$\gamma$ Test $_{\text {zdt-1 }}+\delta \mathrm{HSG}_{\mathrm{izgdt}}+\delta_{\mathrm{g}}+\theta_{\mathrm{t}}+\varepsilon_{\mathrm{izgdt}}$

where $i$ represents the household or housing unit, $z$ represents the attendance zone, $g$ represents the boundary group, $d$ represents the school district and $t$ represents time. $\mathrm{Y}_{\text {izgdt }}$ represents the dependent variables of interest, which include measures of housing demand and neighborhood composition. I examine differences in self-reported housing values and rents, differences in household income as well as changes in the racial composition of households. EverPI $\mathrm{zgt-1}_{1}$ is an indicator variable which identifies whether a school has ever entered program improvement. $\mathrm{PI}_{\mathrm{zgdt}-1}$ is an indicator variable which identifies whether a school is currently in program improvement (lagged one period). PostPI $\mathrm{z}_{\mathrm{zgdt}}$ identifies whether the school was previously in program improvement. PI*Terc23 2 zgdt-1 and PostPI*Terc23 $23_{\text {zgdt-1 }}$ are separate indicators for units in census tracts that are in the second and third terciles within the school district in terms of housing values, interacted with program improvement status. Test $\mathrm{zdt}_{\mathrm{d}-1}$ is a measure of the share of students scoring proficient in each school. $\mathrm{HSG}_{\mathrm{izgdt}}$ represents a set of housing unit level controls, including number of rooms, indicator for a large lot, indicator for no plumbing or kitchen, building type (i.e. single family, 2-4 household buildings, 5- 10 unit buildings, and 11 plus unit buildings) and year unit was built. $\delta_{\mathrm{gt}}$ and $\theta_{\mathrm{z}}$ represent boundary group and year fixed effects, respectively.

\section{Results}

Table 5 presents results for analyses examining the impacts of entering program improvement on real housing values and rents. Beginning with column 1, I find that entering 
program improvement is associated with lower reported housing values in the period immediately after a school enters program improvement as well as for the subsequent periods in my analysis, though these results are not significant at conventional levels. In column 2 , when including indicators for higher value terciles, as in Billings, Brunner and Ross (2014), I find that in these neighborhoods entering program improvement is associated with increases in selfreported housing values, though again these results are not statistically significant. Columns 3 and 4 represent a similar analysis for self-reported rents. We see in column 4 that in lower value neighborhoods there is no significant impact on rents, but that in high value neighborhoods entering program improvement is associated with increases in rents. These results suggest that at least in the neighborhoods with housing values in the second and third tercile, entering program improvement is positively capitalized into housing values. These findings are in line with those of Billings, Brunner and Ross (2014) who argue that in Charlotte-Mecklenburg this result is driven by the increased priority received by households who live in zones with a school in program improvement when entering the lottery for a choice school. As the school districts in this sample have much lower levels of school choice, I will examine whether this result could be driven by additional resources directed towards schools in program improvement.

To examine whether these results are driven by differential sorting, Table 6 presents results describing household composition after a school enters program improvement. These results show that, for neighborhoods in the top terciles by housing values, after a neighborhood school enters program improvement they are more likely to retain or attract higher income, college educated and white households. For those neighborhoods in the bottom tercile of housing values, entering program improvement is associated with attracting or retaining lower income households, who are less likely to be white or college educated. 
These results suggest that entering program improvement could spark differential sorting of households. To further examine whether this is the case, I next estimate the probability that a household will choose a neighborhood that ever entered program improvement. These results provide some additional support for differential sorting occurring after a school entered program improvement. Specifically, college educated and white households are less likely to choose neighborhoods that were ever in program improvement (though these results are not statistically significant), but after a neighborhood school enters program improvement these trends are reversed, and college educated, white households are more likely to enter neighborhoods that are currently in program improvement.

\section{Revised Next Steps}

I am currently collecting school level spending data for these five school districts to determine whether entering school improvement is associated with increased allocations for schools. If this is true, then perhaps the increased housing values and rents are a response to the increased investments made in schools once they enter program improvement. I am also going to explore the choice options available in these districts to examine whether this explanation could apply in the other school districts in my sample.

I hope this research will contribute to our growing understanding of how the incentive structures created through reforming urban public schools are shaping household residential choices. 
References

Baum-Snow, Nathaniel, and Byron F. Lutz. 2012. "School Desegregation, School Choice, and Changes in Residential Location Patterns by Race." The American Economic Review 101 (7): 3019-46.

Billings, S., E. Brunner and S.L. Ross. 2014. "The Housing and Educational Consequences of the School Choice Provisions of NCLB: Evidence from Charlotte, NC." Working Paper.

Black, S. and S. Machin. 2010. "Housing Valuations and School Performance." Prepared for the Handbook of the Economics of Education.

Bogin, Alexander and Phuong Nguyen-Hoang. 2014. "Property Left Behind: An Unintended Consequence of a No Child Left Behind "Failing" School Designation." Journal of Regional Science 54(5): 788-805.

Bonilla, Leonardo, Esteban Lopez, and Daniel Mcmillen. 2015. "House Prices and School Choice: Evidence from Chicago’s Magnet Schools Proximity Lottery." Working Paper.

Boustan, Leah Platt. 2012. "School Desegregation and Urban Change: Evidence from City Boundaries." American Economic Journal: Applied Economics 4 (1): 85-108.

Brunner, Eric J., Sung-Woo Cho, and Randall Reback. 2012. "Mobility, Housing Markets, and Schools: Estimating the Effects of Inter-District Choice Programs." Journal of Public Economics 96 (7-8): 604-14.

Cellini, Stephanie, Fernando Ferreira and Jesse Rothstein. 2010. "The Value of School Facility Investments: Evidence from a Dynamic Regression Discontinuity Design.” Quarterly Journal of Economics, 125(1): 215-261.

Dee, T. and B. Jacob. 2011. "The Impact of No Child Left Behind on Student Achievement." Journal of Policy Analysis and Management, 30(3): 418-446.

Figlio, D.N. and M.E. Lucas. 2004. "What's in a Grade? School Report Cards and the Housing Market." The American Economic Review, 94(3): 591-604.

Machin, Stephen and Kjell G. Salvanes. 2010. "Valuing School Quality via a School Choice Reform.” Working Paper IZA DP No. 4719.

Phuong Nguyen-Hoang and John Yinger. 2011. "The capitalization of school quality into house value: A review." Journal of Housing Economics, 20(1): 30-48.

Reback, Randall, Jonah Rockoff, and Heather L. Schwartz. 2014. "Under Pressure: Job Security, Resource Allocation, and Productivity in Schools under No Child Left Behind." American Economic Journal: Economic Policy 6 (3): 207-41. 
Reber, Sarah J. 2005. "Court-Ordered Desegregation: Successes and Failures Integrating American Schools since Brown versus Board of Education.” J. Human Resources XL (3): $559-90$.

Schwartz, Amy Ellen, Ioan Voicu, and Keren Mertens Horn. 2014. "Do Choice Schools Break the Link between Public Schools and Property Values? Evidence from House Prices in New York City." Regional Science and Urban Economics, 49: 1-10. 
Table 1 Descriptive Characteristics of 5 City Sample

\begin{tabular}{lrrrrr}
\hline & New York City & Los Angeles & Philadelphia & Detroit & Tucson \\
\hline Population & $8,078,471$ & $3,772,486$ & $1,504,950$ & 759,340 & 518,457 \\
\% White & $33.7 \%$ & $29.0 \%$ & $37.3 \%$ & $8.1 \%$ & $48.7 \%$ \\
\% Black & $23.2 \%$ & $9.5 \%$ & $43.0 \%$ & $82.4 \%$ & $4.3 \%$ \\
\% Hispanic & $28.2 \%$ & $48.1 \%$ & $11.6 \%$ & $6.4 \%$ & $40.4 \%$ \\
Poverty Rate & $19.1 \%$ & $19.5 \%$ & $25.1 \%$ & $34.5 \%$ & $21.3 \%$ \\
Share Attend Public School & $80.8 \%$ & $88.8 \%$ & $79.5 \%$ & $93.4 \%$ & $93.0 \%$ \\
\hline
\end{tabular}


Table 2 Descriptive Characteristics of 5 School Districts

\begin{tabular}{lrrrrr}
\hline & New York & \multicolumn{1}{c}{ Los } & & & \\
& \multicolumn{1}{c}{ City } & Angeles & Philadelphia & Detroit & Tucson \\
\hline Number of Schools & 1,474 & 870 & 273 & 182 & 125 \\
Total Enrollment & 992,149 & 670,746 & 165,694 & 90,499 & 55,369 \\
Teacher/Pupil Ratio & 15.3 & 21.4 & 14.9 & 16.9 & 17.8 \\
\% White & $16.5 \%$ & $8.8 \%$ & $12.9 \%$ & $2.5 \%$ & $29.2 \%$ \\
\% Black & $29.1 \%$ & $10.2 \%$ & $56.7 \%$ & $87.2 \%$ & $7.5 \%$ \\
\% Hispanic & $39.0 \%$ & $73.4 \%$ & $16.4 \%$ & $8.0 \%$ & $56.2 \%$ \\
\% Other & $15.3 \%$ & $6.1 \%$ & $6.4 \%$ & $1.2 \%$ & $7.2 \%$ \\
\% Limited English Proficiency & $14.3 \%$ & $31.4 \%$ & $7.3 \%$ & $7.4 \%$ & $7.3 \%$ \\
\% Eligible Free/Reduced Price Lunch & $72.1 \%$ & $76.2 \%$ & $77.2 \%$ & $78.2 \%$ & $54.9 \%$ \\
\hline
\end{tabular}


Table 3 Share of Schools Failing to Meet AYP by Year

\begin{tabular}{llllll}
\hline & $\begin{array}{l}\text { New York } \\
\text { City }\end{array}$ & $\begin{array}{l}\text { Los } \\
\text { Angeles }\end{array}$ & Philadelphia & Detroit & Tucson \\
\hline $2003-2004$ & $11.7 \%$ & $32.1 \%$ & $28.3 \%$ & $45.2 \%$ & $7.3 \%$ \\
$2004-2005$ & $11.8 \%$ & $52.9 \%$ & $38.7 \%$ & $12.5 \%$ & $7.3 \%$ \\
$2005-2006$ & $10.9 \%$ & $42.0 \%$ & $43.9 \%$ & $21.9 \%$ & $17.4 \%$ \\
$2006-2007$ & $9.4 \%$ & $32.8 \%$ & $57.8 \%$ & $19.1 \%$ & $14.5 \%$ \\
$2007-2008$ & $10.9 \%$ & $57.0 \%$ & $56.3 \%$ & $19.1 \%$ & $23.2 \%$ \\
$2008-2009$ & $10.9 \%$ & $53.5 \%$ & $50.0 \%$ & $37.1 \%$ & $14.5 \%$ \\
$2009-2010$ & $10.9 \%$ & $70.1 \%$ & $33.0 \%$ & -- & $27.5 \%$ \\
\hline
\end{tabular}


Table 4 Balancing Test

Dependent Variable:

Ever PI

(1)

Number of Rooms

$-0.002 * * *$

(0.001)

0.006

(0.007)

0.003

(0.014)

0.012

(0.011)

$0.007 * *$

(0.003)

5-10 Unit Apartments

$-0.019 * * *$

(0.003)

$11+$ Unit Apartments

$-0.011 * * *$

(0.003)

Built Pre 1950

$-0.003$

(0.004)

Built Between 1950-1970

$-0.041^{* * *}$

(0.002)

Built Between 1971-1990

$-0.018^{* * *}$

(0.002)

Ln(Real Household Income)

$-0.009 * * *$

(0.001)

$-0.037^{* * *}$

(0.002)

$-0.007^{* *}$

(0.003)

Black

$0.078 * * *$

(0.003)

Hispanic

$0.096 * * *$

(0.003)

(2)

0.000

(0.000)

0.004

(0.004)

$-0.006$

(0.008)

0.005

(0.006)

$-0.001$

(0.002)

$0.006 * *$

(0.002)

0.002

(0.002)

0.002

(0.002)

$-0.003$

(0.002)

$-0.001$

(0.002)

$-0.001$

(0.001)

$-0.003^{*}$

(0.001)

0.003

(0.002)

0.002

(0.003)

$0.005^{* *}$

170,500

(0.002)

N

0.279

170,500

R-sq

$\mathrm{X}$

0.729

City Dummies

X 
Table 5 Housing Values and Rents after a School Enters Program Improvement

\begin{tabular}{lccrr}
\hline & \multicolumn{2}{c}{$\log ($ Real HP) } & \multicolumn{2}{c}{$\log ($ Real Rent) } \\
& \multicolumn{1}{c}{$(1)$} & \multicolumn{1}{c}{$(2)$} & \multicolumn{1}{c}{$(3)$} & $(4)$ \\
\hline EverPI & 0.012 & -0.002 & $-0.041^{* * *}$ & $-0.041^{* * *}$ \\
& $(0.026)$ & $(0.026)$ & $(0.011)$ & $(0.011)$ \\
PI & -0.004 & -0.01 & 0.007 & 0.006 \\
& $(0.024)$ & $(0.034)$ & $(0.010)$ & $(0.012)$ \\
PostPI & -0.026 & -0.029 & $0.021^{*}$ & -0.006 \\
& $(0.028)$ & $(0.039)$ & $(0.013)$ & $(0.016)$ \\
PI*Terc23 & & 0.040 & & -0.001 \\
& & $(0.033)$ & & $(0.013)$ \\
PostPI*Terc23 & & 0.036 & & $0.047^{* * *}$ \\
& & $(0.041)$ & & $(0.018)$ \\
Prof Math and ELA & 0.013 & $0.021^{* *}$ & $0.009 * *$ & $0.009 * *$ \\
& $(0.008)$ & $(0.008)$ & $(0.004)$ & $(0.004)$ \\
Housing Controls & $\mathrm{X}$ & $\mathrm{X}$ & $\mathrm{X}$ & $\mathrm{X}$ \\
Boundary Group FE & $\mathrm{X}$ & $\mathrm{X}$ & $\mathrm{X}$ & $\mathrm{X}$ \\
Year FE & $\mathrm{X}$ & $\mathrm{X}$ & $\mathrm{X}$ & $\mathrm{X}$ \\
$\mathrm{N}$ & 30,000 & 30,000 & 89,200 & 89,200 \\
R-sq & 0.55 & 0.55 & 0.28 & 0.28 \\
\hline
\end{tabular}

*Includes robust standard errors 
Table 6 Household Composition After a School Enters Program Improvement

\begin{tabular}{|c|c|c|c|c|c|c|c|c|c|c|}
\hline & \multicolumn{2}{|c|}{ Log (Real HH income) } & \multicolumn{2}{|c|}{ College Educated } & \multicolumn{2}{|c|}{ White } & \multicolumn{2}{|c|}{ Black } & \multicolumn{2}{|c|}{ Hispanic } \\
\hline & $(1)$ & $(2)$ & (3) & (4) & (5) & (6) & (7) & $(8)$ & (9) & $(10)$ \\
\hline \multirow[t]{2}{*}{ EverPI } & -0.005 & -0.006 & -0.002 & -0.003 & -0.003 & -0.004 & -0.004 & -0.004 & $0.008^{*}$ & $0.009 * *$ \\
\hline & $(0.013)$ & $(0.013)$ & $(0.006)$ & $(0.006)$ & $(0.005)$ & $(0.005)$ & (0.004) & (0.004) & $(0.005)$ & $(0.005)$ \\
\hline \multirow[t]{2}{*}{$\mathrm{PI}$} & -0.005 & -0.022 & -0.007 & $-0.018 * * *$ & -0.002 & $-0.015 * * *$ & 0.001 & 0.006 & 0.002 & $0.018 * * *$ \\
\hline & $(0.012)$ & $(0.015)$ & $(0.005)$ & $(0.006)$ & $(0.005)$ & $(0.005)$ & $(0.004)$ & $(0.005)$ & $(0.004)$ & $(0.006)$ \\
\hline \multirow[t]{2}{*}{ PostPI } & 0.016 & -0.009 & -0.007 & $-0.028 * * *$ & $0.014 * *$ & -0.007 & -0.001 & 0.001 & -0.01 & $0.025 * * *$ \\
\hline & $(0.016)$ & $(0.020)$ & $(0.007)$ & $(0.009)$ & $(0.006)$ & $(0.007)$ & $(0.005)$ & $(0.007)$ & $(0.006)$ & $(0.009)$ \\
\hline \multirow[t]{2}{*}{$\mathrm{PI}$ *Terc23 } & & 0.025 & & $0.017^{* *}$ & & $0.021 * * *$ & & -0.008 & & $-0.025 * * *$ \\
\hline & & $(0.016)$ & & $(0.007)$ & & $(0.006)$ & & $(0.005)$ & & $(0.007)$ \\
\hline \multirow[t]{2}{*}{ PostPI*Terc23 } & & $0.041^{*}$ & & $0.035 * * *$ & & $0.034 * * *$ & & -0.002 & & $-0.058 * * *$ \\
\hline & & $(0.024)$ & & $(0.010)$ & & (0.009) & & (0.008) & & (0.010) \\
\hline \multirow[t]{2}{*}{ ProfMathELA } & $0.019 * * *$ & $0.019 * * *$ & $0.007^{* * *}$ & $0.007 * * *$ & -0.001 & -0.001 & $-0.004 * *$ & $-0.003 * *$ & -0.001 & -0.001 \\
\hline & $(0.005)$ & $(0.005)$ & $(0.002)$ & $(0.002)$ & $(0.002)$ & $(0.002)$ & $(0.001)$ & $(0.001)$ & $(0.002)$ & $(0.002)$ \\
\hline Boundary Group FE & $x$ & $x$ & $x$ & $x$ & $x$ & $x$ & $x$ & $x$ & $x$ & $x$ \\
\hline Year FE & $x$ & $x$ & $x$ & $x$ & $x$ & $x$ & $x$ & $x$ & $x$ & $x$ \\
\hline$N$ & 170,500 & 170,500 & 170,500 & 170,500 & 170,500 & 170,500 & 170,500 & 170,500 & 170,500 & 170,500 \\
\hline R-sq & 0.141 & 0.141 & 0.177 & 0.177 & 0.4 & 0.4 & 0.483 & 0.483 & 0.32 & 0.321 \\
\hline
\end{tabular}

*Includes Robust Standard Errors 